УДК 94(430).063

\title{
КАК НЕМЦЫ КАЗАКОВ ВСТРЕЧАЛИ: ПРЕБЫВАНИЕ КАЗАЧЬЕГО ОТРЯДА Ф.К. ТЕТТЕНБОРНА В ГАМБУРГЕ ВЕСНОЙ 1813 Г.
}

\section{Гунько Андрей Анатольевич}

Научно-образовательный центр "Региональное историко-культурное наследие и кросс-культурные связи", ИИиМО СГУ им. Н.Г. Чернышевского

Аннотация: В данной статье рассматривается встреча гамбургским населением казачьего отряда под командованием Ф.К. Теттенборна в марте 1813 года, опыт «первого контакта» неоднократно подвергался критике в исторической науке. Используя нарративные источники, автор подвергает критике устоявшееся клише об «оккупации» Гамбурга.

Ключевые слова: Наполеон, Гамбург, кампания 1813 года в Германии, имагология, казаки.

\section{HOW THE GERMANS MET THE COSSACKS: THE STAY OF THE COSSACK TROOP OF F.K. TETTENBORN IN HAMBURG IN THE SPRING OF 1813}

\section{Gunko Andrey Anatolevich}

Abstract: This article considered the meeting of the Hamburg population of the Cossack troop under the command of F. K. Tettenborn in March 1813; the experience of the "first contact" which has been repeatedly criticized in historical science. Using narrative sources, the author criticizes the well-established cliché about the "occupation" of Hamburg.

Key words: Napoleon, Hamburg, campaign of 1813 in Germany, Imagology, Cossacks.

В отечественной историографии стало традицией опускать события, происходившие в Германии в 1813 году, отдавая больше предпочтения Бородино 1812 г. или Парижу 1814 года. Однако именно в Германии произошел так называемая «первая встреча» немецкого населения и «русских», представленных в большей степени казаками. Изображаемые наполеоновской 


\section{НАУКА, ОБЩЕСТВО, КУЛЬТУРА: ПРОБЛЕМЫ И ПЕРСПЕКТИВЫ ВЗАИМОДЕЙСТВИЯ В СОВРЕМЕННОМ МИРЕ}

пропагандой казаки как дикие варвары, пришедшие из далекой Сибири, они предстали перед немецкими обывателями в совсем неожиданном для бюргеров образе...

7 (19) марта Теттенборн подошел к Гамбургу, где был встречен «с сердечным восхищением и большой радостью» [1; S. 64]. В полдень его встретил конный отряд из граждан города, которые приветствовали русские войска. Дорога была усыпана цветами. Население следовало за своими освободителями километры: кто на лошадях, кто на повозках, а кто и пешком. У городской заставы казаков встречали толпы народа, славившие русского императора и храбрость русского воинства [2; S. 61]. «Bce окружающие обнимали друг друга и желали счастья. По городу были расставлены украшенные лаврами бюсты императора Александра; полковник Теттенборн держался неподвижно и лишь кричал «Ура!» при виде изображения своего монарха, что охотно подхватывал местный народ...» [3; S. 9].

В три часа зазвонили колокола всех церквей, раздались выстрелы из пушек, извещающие о вступлении в город освободителей. Наконец, показалась русская колонна: впереди Теттенборн с офицерами, затем казаки и калмыки, у которых порой вместо седел были наброшены шкуры, замыкали колонну гусары в красных куртках. Девушки в белых платьях подносили цветы и венки. Женщины поднимали вверх детишек, чтобы военные поцеловали их. Детей постарше пытались подсадить в седла к казакам. Колонна проследовала до рыночной площади Гэнземаркт, где Теттенборна встретила депутаты старого ганзейского сената. Полковнику Теттенборну старшими сенаторами Кохом и Шульцем были поднесены ключи от Гамбурга, а три девочки в белых платьях увенчали его венком с надписью: «Божественному вестнику счастливых времен!». На набережной Юнгфернштиг уже с утра был приготовлен длинный стол для угощения военных. Здесь же казаки расположились потом под открытым небом на ночлег. Таким образом, отряд медленно прошел через Штайнштрассе, через конный рынок, через Цухтаусстрассе, Юнгфернштиг, Нойенволл, Эллентхорсбрюке и Фюлентвите к Гэнземаркту [2; S. 63].

Самое большое впечатление на гамбуржцев произвели казаки и калмыки. Своей невиданной бородатостью, мохнатыми шапками, потрепанной на дальних переходах одеждой, собранной подчас из разных предметов, в том числе и позаимствованных у побежденных французов. Группы людей окружали казаки расположившихся на улицах, особенно в Юнгфернштиге, на рынке, в Св. Георгия, разговаривали с ними жестами; горожане быстро подружились с 


\section{НАУКА, ОБЩЕСТВО, КУЛЬТУРА: ПРОБЛЕМЫ И ПЕРСПЕКТИВЫ ВЗАИМОДЕЙСТВИЯ В СОВРЕМЕННОМ МИРЕ}

иноземцами, одаривая друг друга небольшими подарками, и чувствовали себя самыми счастливыми, если они получали от них поцелуй [2; S. 65].

Любопытные горожане в эти дни толпились на набережной Юнгфернштиг, рассматривая устроившихся на бивуак русских военных. На площади были установлены столы для рассадки войск; было приготовлено много еды [2; S. 63]. Поскольку никто из гамбуржцев не понимал по-русски, находчивые торговцы тут же издали небольшой словарик, который начинался словами «вино, водка, пиво, вода» [5]. Тонны картофельного салата и маринованной селедки и ведра водки были предоставлены на радость гостям; всё, как любили казаки. Теттенборна поселили в бывшей резиденции Даву, откуда он вечером отправился в театр. Как только он вошел в зал, все находящиеся внутри встали поприветствовать «Спасителя Гамбурга». После небольшого пролога от Мадам Шрёдер началась пьеса «Русские в Германии», закончившаяся всеобщем исполнением песни «За благополучие Гамбурга!» [2; 64-65]. В последующие дни праздничное настроение не оставляло горожан. Из пригородов прибывали люди, чтобы посмотреть на русских казаков. И хотя общение с ними ограничивалось жестикуляцией, всеобщая радость была явной. Торжества продолжались до двух часов ночи, музыка и веселье ни на минуту не угасали [3; S. 9-10; 4].

О характере пребывания Теттенборна ярко выразился в своем сочинении непосредственный участник тех событий - И.Л. фон Гесс. Гесс, будучи главой управления местной милиции, пересказывая слухи от высокопоставленных военнослужащих, приводит слова Теттенборна о том, что он «до самого последнего момента держался всеми возможными средствами», но оборонять город - заключает Гесс - по факту больше не мог (также он отвергает все обвинения в сторону Теттенборна о том, что он фактически оккупировал Гамбург, приводя в аргумент факт того, что Теттенборн беспрекословно подчинялся приказам императора Александра) [1; S. 359]. Также Гесс упрекает городской Сенат, что на протяжение последних дней независимости Гамбурга он проявлял некую отрешенность от событий, чем окончательно утратил к себе и без того малое доверие [1; S.365].

Однако необходимо отметить, что такую радостную атмосферу прибытия казаков Теттенборна в Гамбург рисуют не все исследователи. Так Кэтрин Ааслештад оценивает прибытие Теттенборна и «его русских» в город как «великое разочарование»: «он [Теттенборн] и его люди наслаждались радостной жизнью находясь в Гамбурге, а горожане были вынуждены платить 


\section{НАУКА, ОБЩЕСТВО, КУЛЬТУРА: ПРОБЛЕМЫ И ПЕРСПЕКТИВЫ ВЗАИМОДЕЙСТВИЯ В СОВРЕМЕННОМ МИРЕ}

за это» [6; Р. 661]. Исследовательница несправедливо обвиняет Теттенборна в военной не компетенции и «непомерной жадности». В своей работе она дает такую характеристику Теттенборну: «Жадность Теттенборна была сравнима с его военной некомпетентностью: он тратил много времени и денег, устраивая дикие вечеринки, вместо того, чтобы планировать оборону города; прикарманил часть средств, которые собрали для Ганзейского Легиона. Дары в виде еды и питья, которые казакам свободно раздавали в первый же день пребывания их в городе, превращались в обязательства, которые требовали русские войска. Хотя они прибыли сюда только с поклажей, которую могли увезти на себе, покинули они Гамбург с тяжело нагруженными лошадьми и вереницей тянувшихся за ними повозок» [6; Р. 661]. Однако, стоит отметить важную деталь, которая, по непонятным для нас причинам, ускользает от взора исследовательницы: эти запасы уходили на содержание казачьих отрядов и были собраны жителями Гамбурга добровольно. Это подтверждают множество источников (например, воспоминания И.Л. фон Гесса [1] или письма Э.Х. Кампэ [3]) и исследований (Мёнкеберга [2] или да Луза [7]). Не достанься они коалиционным войскам, они бы наверняка отошли бы имперскому правительству.

Р. Делдерфилд в крайне негативном ключе высказывается по поводу вступления казаков в Гамбург весной 1813 г. В своей работе он писал: «Приветствуя казаков так, словно они освободили их из рабских цепей, граждане древнего торгового центра предоставили им доступ к своим богатейшим запасам товаров, провизии и напитков. Если бы они знали казаков лучше, они бы понимали, что такая щедрость в данном случае является явно неуместной. Рядовой казак был самым отъявленным грабителем в мире, не исключая и грабителей профессиональных, и в любом случае в походе он не упускал шанса приобрести то, в чем он мог нуждаться или что он мог пожелать в своей собственной стране или в любой другой. Именно это он и делал в Гамбурге, следуя примеру своих командиров» [8; с. 28]. Все эти рассуждения, на наш взгляд, не имеют никаких фактических оснований (с точки зрения исторических свидетельств) и являются детищем так называемой «войны перьев» в процессе деятельности наполеоновской пропаганды.

Гамбург, который столетия бережно охранял и защищал свою независимость, столкнулся на рубеже XVIII-XIX веков с мощным бюрократическим аппаратом Наполеоновской Империи. Оказавшись невольной жертвой геополитических авантюр Наполеона, население Вольного города 


\section{НАУКА, ОБЩЕСТВО, КУЛЬТУРА: ПРОБЛЕМЫ И ПЕРСПЕКТИВЫ ВЗАИМОДЕЙСТВИЯ В СОВРЕМЕННОМ МИРЕ}

(преимущественно купцы) до последнего пытались выторговать наиболее выгодные для себя условия оккупации. Но, как мы увидели, не добившись официального разрешения торговать с Англией и США (это было невозможно благодаря Берлинскому декрету), купцы некогда могущественной Ганзейской Лиги теперь нашли свое утешение в контрабанде, ухищряясь проносить через границы уже Французской Империи колониальные товары в местах, которые им только позволяла их фантазия.

Наполеон же, осознав, что что-то в его плане по удушению британской экономики идет не так, 1 января 1811 года (по новому стилю) окончательно лишает Гамбург, Бремен и Любек любой, даже юридической, самостоятельности, присоединяя их к своей могущественной Империи, несмотря на свое официальное «благосклонное отношение», символически отраженное на новом гербе города. Терпение бюргеров города, казну которого Наполеон превратил в личный кошелек, ожидаемо лопнуло. Славные победы, которые одержали союзные войска на протяжении всей Заграничной кампании, были бы невозможны без деятельности диверсионных отрядов, куда входили казаки.

Тем не менее, несмотря на весьма благосклонное отношение немецких жителей к казачьим отрядам, празднества в честь казаков и, искреннюю радость освобождения, немецкие буржуа не рискнули бороться до конца за свою свободу перед лицом превосходящих сил противника. Существенная военная помощь Теттенборну как со стороны горожан, так и от Союзников не была оказана, людских ресурсов катастрофически не хватало, за что город и поплатился. Но эта тема требует отдельного обсуждения...

\section{Список литературы}

1. Heß J. L. von. Agonieen der Republik Hamburg im Frühjahr 1813. Hamburg, 1816. S. 64.

2. Mönckeberg C., Nolte G. E. (Hrsg.) Hamburg, unter dem Drucke der Franzosen: 1806-1814: historische Denkwürdigkeiten. Hamburg, 1864. S. 64-65.

3. Campe E. H. Hamburgs außerordentliche Begebenheiten und Schicksale in den Jahren 1813 und 1814. Hamburg, 1814. S. 9.

4. A letter by Colonel Hamilton, Lieutenant-Governor of Heligeland, dated 23d March, 1813. // The London Gazette № 16715. [Электронный ресурс]. URL: https://www.thegazette.co.uk/London/issue/16715/page/639 (дата обращения 25.02.2019). 
5. 1813 г. В Гамбурге - русские! [Электронный ресурс]. URL: https://samsud.ru/news/1813-g-v-gamburge-russkie.html (дата обращения 22.02.2019).

6. Aaslestad K.B. Paying for War: Experiences of Napoleonic Rule in the Hanseatic Cities. Vol. 39, Issue 4, 2006. P. 661.

7. Luz H.S. da. «Franzosenzeit» in Norddeutschland (1803-1814). Napoleons Hanseatische Departements. Temmen, Bremen, 2003.

8. Делдерфилд Р. Закат империи. М., 2002. 